\title{
Respon Inseminator terhadap Penerapan Transfer Embrio di Kabupaten Lampung Tengah
}

\section{Inseminator Response for Embrio Transfer Implementation in Lampung Tengah Regency}

\author{
G. Vivi ${ }^{1}$, R. Noviadi ${ }^{1}$, dan T. Rumiyani ${ }^{1}$ \\ ${ }^{1}$ Jurusan Peternakan Politeknik Negeri Lampung, \\ Jln. Soekarno Hatta No 10 Rajabasa Bandar Lampung, 35144 \\ *E-mail korespondensi: riko_noviadi@ polinela.ac.id
}

\begin{abstract}
Efforts to apply embryo transfer reproductive technology to community breeders in Lampung Tengah Regency involve inseminators who have an interest and influence in the success of embryo transfer. This study aims to analyze the inseminator response to the implementation of embryo transfer in Lampung Tengah Regency by looking at the influence of age (X1), education level (X2), work experience (X3), knowledge (X4), means of transportation (X5), and facilities and infrastructure (X6) owned by the inseminator of the inseminator's response to the application of embryo transfer in Lampung Tengah Regency. The analytical method used is simple linear regression analysis of 28 inseminators on duty in Lampung Tengah Regency. The results showed that the more productive the inseminator age (old), the lower the inseminator response. Meanwhile, the level of education, work experience, knowledge, means of transportation, and facilities and infrastructure owned by the inseminator in Lampung Tengah did not have a significant positive effect on the inseminator's response regarding the implementation of embryo transfer in Lampung Tengah Regency, Lampung Province.
\end{abstract}

Keywords: embryo transfer, implementation, inseminator response

Diterima: 15 Februari 2021, disetujui 15 Agustus 2021

\section{PENDAHULUAN}

Lampung Tengah merupakan salah satu kabupaten yang ada di Provinsi Lampung yang memiliki wilayah daratan seluas 4.789,82 $\mathrm{km}^{2}$ dan merupakan daerah agraris (BPS Lampung Tengah, 2018) dengan luas lahan yang didominasi oleh sektor pertanian dan memiliki potensi dalam subsektor peternakan, dimana Lampung Tengah dikenal dengan lumbung ternak Provinsi Lampung. Hal ini dikarenakan jumlah populasi sapi yang ada di Lampung sebagian besar berada di Lampung Tengah.

Dinas Peternakan Kabupaten Lampung Tengah (2019b), populasi sapi potong di Lampung Tengah berjumlah 273.136 ekor terdiri atas 128.503 ekor jantan dan 144.663 ekor betina. Banyaknya populasi sapi ini telah menjadi perhatian pemerintah Kabupaten Lampung Tengah sehingga adanya program-program yang dicanangkan untuk meningkatkan perkembangan ternak sapi potong. Salah satu program yang sudah dijalankan yaitu program Inseminasi Buatan (IB) secara massal disetiap kecamatan untuk merealisasikan program UPSUS SIWAB (Upaya Khusus Sapi Indukan Wajib Bunting).

Adapun teknologi reproduksi pada ternak mengalami suatu perkembangan dan sekarang ini sudah adanya inovasi baru dari IB yaitu transfer embrio. Transfer Embrio (TE) merupakan teknologi reproduksi yang dipakai dalam program pemuliaan ternak dengan memanfaatkan bibit induk betina unggul dan juga jantan unggul secara maksimal untuk peningkatan produktivitas (jumlah dan kualitas) ternak (Supriatna, 2018). Hasil yang didapatkan dari teknologi ini yaitu bibit sapi yang memiliki kualitas terbaik, sehingga bibit-bibit tersebut dapat dimanfaatkan sebagai penghasil semen untuk kebutuhan IB (jantan) sedangkan betina dapat digunakan sebagai indukan (Yusnaweti et al., 2013). 
Inseminator tidak hanya berperan dalam teknologi reproduksi IB namun juga berperan dalam teknologi reproduksi TE yang bertugas dalam mentransfer embrio ke dalam uterus. Maka dalam penerapan suatu program pemerintah mengenai teknologi reproduksi ternak akan melibatkan inseminator yang memiliki kepentingan dan memberi pengaruh dalam menjalankan suatu program peternakan. Pada data Dinas Peternakan Kabupaten Lampung Tengah (2019a) bahwa petugas IB (Inseminator) di Kabupaten Lampung Tengah sebanyak 152 orang yang tersebar dalam 28 wilayah Lampung Tengah, dan beberapa inseminator bertugas juga sebagai Pemeriksa Kebuntingan (PKb) dan Asisten Teknis Reproduksi (ATR).

Respon inseminator akan memengaruhi dalam pengembangan sebuah teknologi reproduksi karena inseminator merupakan peran utama dalam pengembangan program Pemerintah. Keahlian dan keterampilan inseminator adalah faktor utama terjadinya keberhasilan induk menjadi bunting serta kemampuan dalam pemeriksaan kebuntingan setelah di IB. Respon akan memberikan reaksi yang timbul dari faktor yang diberikan karena setiap individu memiliki persepsi dan penafsiran yang akan membentuk sikap dan perilaku. Respon inseminator dalam penerapan TE di Kabupaten Lampung Tengah akan berpengaruh pada program Pemerintah dalam pengembangan teknologi reproduksi untuk mendukung swasembada daging nasional.

\section{METODE PENELITIAN}

Penelitian ini dilaksanakan di Kecamatan Seputih Raman, Kecamatan Seputih Mataram, dan Kecamatan Terbanggi Besar yang ada di Kabupaten Lampung Tengah, Provinsi Lampung. Bahan yang digunakan yaitu kuesioner yang digunakan sebagai hasil data dalam penelitian sehingga data dapat dijadikan hasil analisis.

Metode pengumpulan data yang digunakan yaitu dengan cara observasi, wawancara dan studi literatur. Observasi dilakukan dengan mengamati langsung dengan mencatat secara sistematik obyek yang akan diteliti, wawancara digunakan untuk mengumpulkan data primer dengan wawancara langsung kepada responden yaitu inseminator Lampung Tengah, dan studi literatur digunakan untuk menganalisa obyek penelitian secara teoritis terhadap masalah-masalah yang berhubungan dengan penulisan, melalui pustaka berbagai jurnal ilmiah dan skripsi, artikel-artikel yang relevan, serta sumber lain yang mendukung data sekunder.

Penarikan sampel responden untuk inseminator dilakukan dengan menggunakan metode acak sederhana (Simple Random Sampling) yaitu jumlah sampel diambil dari 3 Kecamatan yang memiliki jumlah inseminator terbanyak di Lampung Tengah. Kemudian ditentukan menggunakan rumus slovin dengan batas toleransi sebesar 10\% (Sevilla et al., 2007 dalam Supriyanto dan Iswandari, 2017).

Peubah pada penelitian ini adalah peubah respon yang didefinisikan sebagai suatu pandangan dan pendapat inseminator terhadap penerapan transfer embrio di Kabupaten Lampung Tengah. Pengukuran peubah menggunakan skala likert dengan jawaban dari setiap pertanyaan dan pernyataan dihubungkan dengan jawaban berupa dukungan atau pernyataan sikap yang diberikan skor 1-3.

Pengujian hipotesis yaitu dengan analisis regresi linier sederhana untuk mengetahui faktor- faktor yang memengaruhi respon inseminator terhadap penerapan transfer embrio di Kabupaten Lampung Tengah. Kemudian dilanjutkan dengan kriteria pengujian regresi linier sederhana yaitu jika Fhitung $\geq$ Ftabel maka hipotesis diterima, dan jika Fhitung $\leq$ Ftabel maka hipotesis diterima. Menurut Wijayanti et al. (2016), analisis regresi linier sederhana digunakan dengan rumus:

$$
\mathrm{Y}=\mathrm{A}+\mathrm{BX}_{1,2,3, \ldots \mathrm{n}}
$$

Keterangan :

Y : Respon

A : Konstanta
B : Koefisien regresi

$\mathrm{X}_{1,2,3 . \mathrm{n}}$ : Peubah yang diamati 


\section{HASIL DAN PEMBAHASAN}

Berdasarkan pengujian analisis regresi linier sederhana, peubah dependen adalah respon inseminator terhadap penerapan transfer embrio di Kabupaten Lampung Tengah (Y) dan peubah independen (X) yaitu umur (X1), tingkat pendidikan (X2), pengalaman kerja (X3), pengetahuan (X4). Hasil analisis regresi linier sederhana dapat dilihat pada Tabel 1.

Tabel 1. Hasil analisis regresi linier sederhana terhadap respon inseminator terhadap penerapan transfer embrio di Kabupaten Lampung Tengah

\begin{tabular}{clccccc}
\hline No & \multicolumn{1}{c}{ Peubah } & $\begin{array}{c}\text { Koefisien } \\
\text { Regresi }\end{array}$ & Konstanta & F Hitung & F Tabel & Ket \\
\hline 1 & Umur $\left(\mathrm{X}_{1}\right)$ & $-0,627$ & 7,375 & 3,603 & 4,21 & NS \\
2 & Tingkat pendidikan $\left(\mathrm{X}_{2}\right)$ & 0,037 & 6,270 & 0,008 & 4,21 & NS \\
3 & Pengalaman kerja $\left(\mathrm{X}_{3}\right)$ & 0,032 & 6,259 & 0,010 & 4,21 & NS \\
4 & Pengetahuan $\left(\mathrm{X}_{4}\right)$ & 1,000 & 4,750 & 3,940 & 4,21 & NS \\
\hline
\end{tabular}

Ket : NS : Non Signifikan

\section{Umur (X1)}

Nilai hasil analisis diperoleh F hitung < F tabel menunjukan bahwa peubah umur inseminator tidak berpengaruh nyata terhadap respon inseminator mengenai penerapan transfer embrio di Kabupaten Lampung Tengah. Persamaan regresi linier pengaruh peubah umur inseminator pada respon inseminator terhadap penerapan transfer embrio di Kabupaten Lampung Tengah apabila disajikan dalam bentuk grafik dengan asumsi peubah lainnya konstan dapat dilihat pada Gambar 1.

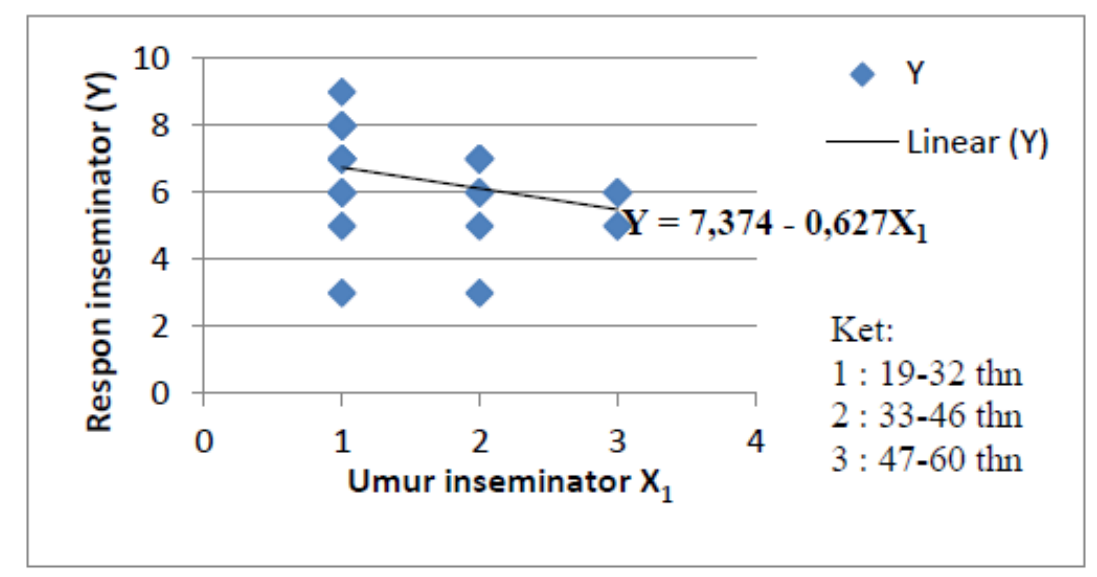

Gambar 1. Grafik pengaruh umur terhadap respon inseminator terhadap penerapan transfer embrio di Kabupaten Lampung Tengah

Berdasarkan nilai konstanta persamaan regresi diperoleh nilai sebesar 7,374, apabila tidak ada pengaruh peubah umur inseminator $(X=0)$ maka nilai dari respon inseminator sebesar 7,374. Nilai koefisien regresi peubah umur sebesar $-0,627$ yang menyatakan bahwa setiap penambahan satu satuan peubah umur inseminator memiliki kecenderungan menurunkan peubah respon inseminator sebesar 0,627. Menunjukan bahwa semakin tidak produktif (tua) umur inseminator maka semakin rendah respon inseminator terhadap penerapan transfer embrio di Kabupaten Lampung Tengah. Hal ini selaras dengan pendapat Hastuti et al. (2008) bahwa umur muda akan lebih bersikap terbuka dan berani untuk mencoba menerapkan suatu teknologi guna meningkatkan produktivitas usaha ternak.

\section{Tingkat Pendidikan (X2)}

Nilai hasil analisis diperoleh $\mathrm{F}$ hitung $<\mathrm{F}$ tabel menunjukan bahwa peubah tingkat pendidikan inseminator tidak berpengaruh nyata terhadap respon inseminator mengenai penerapan transfer embrio di 
Kabupaten Lampung Tengah. Persamaan regresi linier pengaruh peubah tingkat pendidikan inseminator pada respon inseminator terhadap penerapan transfer embrio di Kabupaten Lampung Tengah apabila disajikan dalam bentuk grafik dengan asumsi peubah lainnya konstan dapat dilihat pada Gambar 2.

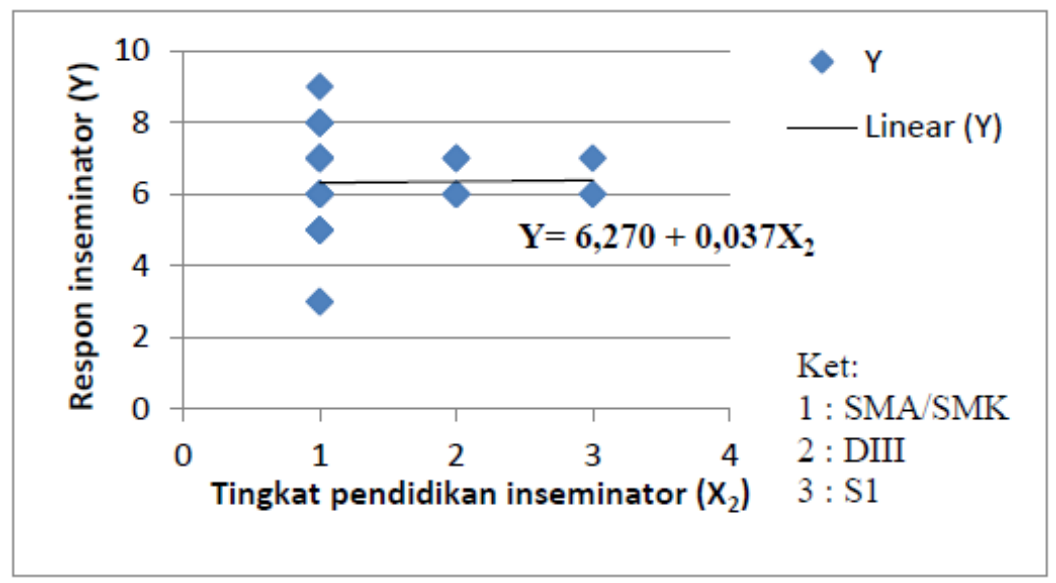

Gambar 2. Grafik pengaruh tingkat pendidikan terhadap respon inseminator terhadap penerapan transfer embrio di Kabupaten Lampung Tengah

Berdasarkan nilai konstanta persamaan regresi diperoleh nilai sebesar 6,270, apabila tidak ada pengaruh peubah tingkat pendidikan inseminator $(X=0)$ maka nilai dari respon inseminator sebesar 6,270. Nilai koefisien regresi peubah tingkat pendidikan sebesar 0,037 yang menunjukan bahwa setiap penambahan satu satuan peubah tingkat pendidikan inseminator memiliki kecenderungan menaikkan peubah respon inseminator sebesar 0,037 .

Perbedaan tingkat pendidikan inseminator semestinya memengaruhi pola pikir inseminator dalam menerima adanya adopsi teknologi transfer embrio seperti yang dikatakan Astuti et al. (2016) bahwa tingkat pendidikan memengaruhi cara berpikir terhadap respon-respon inovatif dan perubahan-perubahan yang dianjurkan. Inseminator yang tingkat pendidikannya lebih tinggi seharusnya dapat memberikan respon yang tinggi dengan adanya inovasi teknologi reproduksi transfer embrio. Namun tidak demikian halnya pada inseminator di Lampung Tengah.

Proses belajar tidak mutlak diperoleh di pendidikan formal, akan tetapi juga dapat diperoleh pada pendidikan non formal. Pendidikan non formal yang diperoleh petugas inseminator Lampung Tengah yaitu pendidikan inseminasi (kursus IB) sebagai syarat menjadi inseminator. Selain menjadi inseminator, terdapat sebanyak 89,3\% inseminator bertugas sebagai Asisten Teknis Reproduksi (ATR) dan Pemeriksaan Kebuntingan $(\mathrm{PKb})$ serta 10,7\% inseminator bertugas sebagai Pemeriksaan Kebuntingan $(\mathrm{PKb})$.

Sehingga dengan pendidikan non formal yang diperoleh inseminator Lampung Tengah maka diharapkan dapat memengaruhi proses belajar yang dapat dengan mudah menerima informasi dan inovasi yang terus berkembang. Program penyuluhan dan pelatihan dari pemerintah daerah tentang teknologi reproduksi transfer embrio kepada inseminator Lampung Tengah diperlukan guna membantu pemahaman dan keterampilan inseminator terhadap transfer embrio dan dapat terealisasikan penerapan transfer embrio di Lampung Tengah untuk mewujudkan Lampung Tengah sebagai penghasil bakalan yang unggul dan berkualitas.

\section{Pengalaman Kerja Inseminator (X3)}

Nilai hasil analisis diperoleh $\mathrm{F}$ hitung < F tabel menunjukan bahwa peubah pengalaman kerja inseminator tidak berpengaruh nyata terhadap respon inseminator mengenai penerapan transfer embrio di Kabupaten Lampung Tengah. Persamaan regresi linier pengaruh peubah pengalaman kerja inseminator pada 
respon inseminator mengenai penerapan transfer embrio di Kabupaten Lampung Tengah apabila disajikan dalam bentuk grafik dengan asumsi peubah lainnya konstan dapat dilihat pada Gambar 3 .

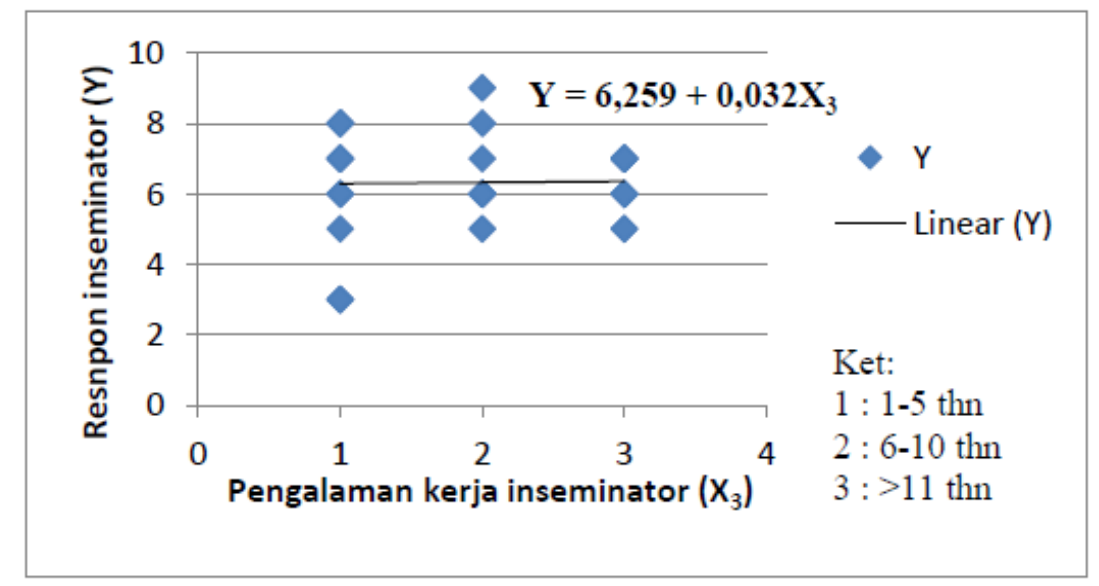

Gambar 3. Grafik pengaruh pengalaman kerja inseminator terhadap respon inseminator terhadap penerapan transfer embrio di Kabupaten Lampung Tengah

Berdasarkan nilai konstanta persamaan regresi diperoleh nilai sebesar 6,259, apabila tidak ada pengaruh peubah pengalaman kerja inseminator $(X=0)$ maka nilai dari respon inseminator sebesar 6,259. Nilai koefisien regresi peubah pengalaman kerja sebesar 0,032 yang menunjukan bahwa setiap penambahan satu satuan peubah pengalaman kerja inseminator memiliki kecenderungan menaikkan peubah respon inseminator sebesar 0,032 .

Menurut Indrayani dan Andri (2018) dengan pengalaman yang cukup lama peternak memiliki pemahaman yang lebih baik terhadap usahat ternak yang dijalankannya. Pengalaman kerja inseminator yang cukup lama semestinya dapat menerima adanya perkembangan teknologi reproduksi dan dapat memberikan pengetahuan serta mengajak peternak masyarakat dalam mengenal dan menerapkan teknologi reproduksi transfer embrio guna meningkatan populasi dan meningkatkan pendapatan ekonomi peternak masyarakat. Namun di lapangan tidak diperoleh pengaruh yang diharapkan.

Pada penelitian juga didapatkan bahwa 7,2\% inseminator pernah mengikuti pelatihan transfer embrio dan $92,8 \%$ inseminator belum pernah mengikuti pelatihan transfer embrio. Hasil ini mengindikasikan bahwa inseminator responden yang belum pernah mengikuti pelatihan transfer embrio lebih mendominasi sehingga pengalaman kerja mengenai transfer embrio di lapangan masih kurang. Pendapat Tarmizi (2018) bahwa sulitnya belajar dari pengalaman di lapangan maka akan sulit juga dalam menerima inovasi teknologi usaha tani menuju perubahan baik secara individu maupun kelompok.

\section{Pengetahuan Inseminator (X4)}

Nilai hasil analisis diperoleh $\mathrm{F}$ hitung $<\mathrm{F}$ tabel menunjukan bahwa peubah pengetahuan inseminator tidak berpengaruh nyata terhadap respon inseminator mengenai penerapan transfer embrio di Kabupaten Lampung Tengah. Persamaan regresi linier pengaruh peubah pengetahuan inseminator pada respon inseminator terhadap penerapan transfer embrio di Kabupaten Lampung Tengah apabila disajikan dalam bentuk grafik dengan asumsi peubah lainnya konstan dapat dilihat pada Gambar 4.

Berdasarkan nilai konstanta persamaan regresi diperoleh nilai sebesar 4,75, apabila tidak ada pengaruh peubah pengetahuan inseminator $(X=0)$ maka nilai dari respon inseminator sebesar 4,75 . Nilai koefisien regresi peubah pengetahuan sebesar 1 yang menunjukan bahwa setiap penambahan satu satuan peubah pengetahuan inseminator memiliki kecenderungan menaikkan peubah respon inseminator sebesar 1 .

Menurut Astuti et al. (2014) menyatakan bahwa peningkatan pengetahuan petani mencerminkan tingkat kesadaran mereka untuk mencari dan menerima informasi inovasi teknologi. Namun keadaan di lapangan tidak demikian, tidak banyak inseminator yang menerima perkembangan teknologi reproduksi 
transfer embrio karena mengganggap bahwa secara ekonomi untuk harga embrio relatif mahal, untuk mengenalkan transfer embrio ke peternak masyarakat cukup sulit dan keterampilan inseminator yang masih kurang.

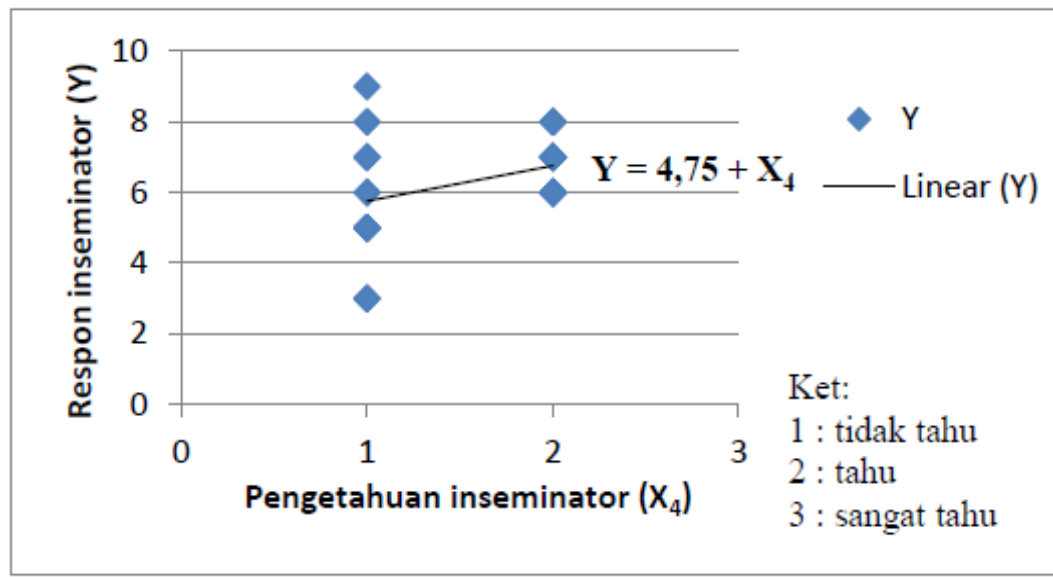

Gambar 4. Grafik pengaruh pengetahuan terhadap respon inseminator terhadap penerapan transfer embrio di Kabupaten Lampung Tengah

Banyaknya tanggapan inseminator tersebut pendekatan oleh Pemerintah Daerah dengan cara penyuluhan merupakan kegiatan yang tepat untuk menerapkan transfer embrio di Lampung Tengah. Hal ini sejalan dengan pendapat Winaryanto et al. (2017) bahwa peran penyuluh sebagai individu yang mampu membantu peternak agar dapat berpartisipasi dalam kegiatan beternak yang mampu mendengarkan aspirasi dan memberikan dukungan kepada peternak serta upaya mendekatkan sumber- sumber informasi kepada peternak sehingga mempermudah dalam proses penerimaan inovasi baru, dan pada akhirnya mudah untuk diterapkan.

\section{KESIMPULAN}

Umur inseminator yang semakin produktif (tua) maka semakin rendah respon inseminator, sedangkan tingkat pendidikan, pengalaman kerja, pengetahuan, alat transportasi, serta sarana dan prasarana yang dimiliki inseminator di Lampung Tengah tidak memberikan pengaruh secara positif terhadap respon inseminator mengenai penerapan transfer embrio di Kabupaten Lampung Tengah, Provinsi Lampung.

\section{DAFTAR PUSTAKA}

Astuti, U. P., Harta, L. dan Silviyani, E. 2016. Evaluasi Pelaksanaan Penyuluhan terhadap Tingkat Pengetahuan Teknologi Silase Pembuatan Pakan Ternak di Kecamatan Talang Empat. Prosiding Seminar Nasional Agroinovasi Spesifik Lokasi Untuk Ketahanan Pangan Pada Era Masyarakat Ekonomi ASEAN (1): 1604-1610.

Astuti, U. P., Sugandi, D. dan Hamdan. 2014. Faktor-Faktor Yang Memengaruhi Adopsi Petani Terhadap Inovasi Teknologi Jeruk Gerga Lebong di Provinsi Bengkulu. Prosiding Perlindungan dan Pemberdayaan Pertanian dalam Rangka Pencapaian Kemandirian Pangan Nasional dan Peningkatan Kesejahteraan Petani. 79-85 hal.

BPS Lampung Tengah. 2018. Kabupaten Lampung Tengah Dalam Angka. BPS Kabupaten Lampung Tengah. Lampung Tengah. 
Dinas Peternakan Kabupaten Lampung Tengah. 2019a. Lokasi Satuan Pelayanan Inseminasi Buatan, POS Pelayanan IB, dan Nama-Nama Petugas IB, PKb, dan ATR. Lampung Tengah.

Dinas Peternakan Kabupaten Lampung Tengah. 2019b. Populasi Ternak Kabupaten Lampung Tengah Tahun 2018. Lampung Tengah.

Hastuti, D., Nurtini, S. dan Widiati, R. 2008. Kajian sosial ekonomi pelaksanaan inseminasi buatan sapi potong di Kabupaten Kebumen. Mediagro 4(2): 1-12.

Indrayani, I. dan Andri, A. 2018. Faktor-faktor yang mempengaruhi pendapatan usaha ternak sapi potong di Kecamatan Sitiung, Kabupaten Dharmasraya. Jurnal Peternakan Indonesia (Indonesian Journal of Animal Science) 20(3): 151.

Supriatna, I. 2018. Transfer Embrio Pada Ternak Sapi. Seameo Biotrop. Bogor. 1-134 hal.

Supriyanto, W. dan Iswandari, R. 2017. Kecenderungan sivitas akademika dalam memilih sumber referensi untuk penyusunan karya tulis ilmiah di perguruan tinggi. Berkala Ilmu Perpustakaan dan Informasi 13(1): 79.

Tarmizi, N. B. 2018. Keberhasilan inseminasi buatan (IB) pada sapi aceh menggunakan semen beku sapi bali, simental, dan limosin di Kecamatan Mesjid Raya Kabupaten Aceh Besar. Jurnal Ilmiah Mahasiswa Veteriner 2(3): 318-328.

Wijayanti, A., Subejo, S. dan Harsoyo, H. 2016. Respons petani terhadap inovasi budidaya dan pemanfaatan sorgum di Kecamatan Srandakan Kabupaten Bantul. Agro Ekonomi 26(2): 179.

Winaryanto, S., Yunasaf, U., Rochana, A., Hernaman, I., Dhalika, T., Wiradimadja, R. dan Rusmana, D. 2017. Respon Peternak Terhadap Peran Penyuluhan dalam Penerapan Pelatihan Teknologi Permintax Sebagai Suplementasi Ransum Berbasis Bahan Pakan Lokal. Prosiding Seminar Nasional Hasil Penelitian Agribisnis1 FP UNIGAL 2017 923-928.

Yusnaweti, Muhamad, R. dan Nasrul, W. 2013. Model penyebaran teknologi embrio transfer sapi potong lintas wilayah kabupaten Provinsi Sumbar. Menara Ilmu 2(35): 46-53. 